\title{
G. E. Moore and theory of moral/right action in ethics of social consequences
}

\author{
Vasil Gluchman
}

\begin{abstract}
G. E. Moore's critical analysis of right action in utilitarian ethics and his consequentialist concept of right action is a starting point for a theory of moral/right action in ethics of social consequences. The terms right and wrong have different meanings in these theories. The author explores different aspects of right and wrong actions in ethics of social consequences and compares them with Moore's ideas. He positively evaluates Moore's contributions to the development his theory of moral/right action.
\end{abstract}

Keywords: G. E. Moore, right, wrong, ethics of social consequences

\section{Introduction}

When formulating the theory of moral/right action in ethics of social consequences, ${ }^{1}$ I took inspiration from G. E. Moore's critical analysis of right action in utilitarian ethics and his consequentialist concept of right action (Moore, 2000; 2005), which I adopted as the starting point of my reasoning (Gluchman, 2000, pp. 9-23; 2001, pp. 633-634). I follow the view of action similar to that of Moore, which means he evaluates the actions of a moral agent on the basis of their consequences. However, unlike Moore, I form in ethics of social consequences a broader scope of evaluative judgements, ${ }^{2}$ and what is also broader is the value structure of ethics of social consequences, as among the fundamental values there are humanity, human dignity, the moral right of man to life, its development and cultivation, as well as the values of justice, responsibility, tolerance and obligation (Gluchman, 2003; 2009, pp. 73-86; 2013, pp. 111-130; 2017, pp. 131-144). The aim of the article is analyse Moore's ideas of right and compare them with my theory of moral/right action (in ethics of social consequences).

\section{Two theories of right action}

In ethics of social consequences, contrary to Moore, the terms right and wrong have different meanings. While in Moore, right and wrong are priority evaluative judgements, in ethics of social consequences, they are only of secondary importance, as the main evaluative

\footnotetext{
${ }^{1}$ In the context of the concepts of Philip Pettit, Amartya Sen, Michael Slot and Frank Jackson, ethics of social consequences started to form in the mid 1990s as a version of non-utilitarian consequentialism. The formulation of the theory of moral/right action and the concept of individual, or collective, moral agent by means of his/her intellectual and cognitive abilities, such as reasoning, decision making, behaving, acting and evaluating could be considered the most significant contribution to contemporary ethics of social consequences (Dubiel-Zielińska 2013; 2015; 2016; Domagała 2015; Gluchman 2007; 2012; 2016; Gluchmanová 2013; Kalajtzidis 2013; Misseri 2014; Sachdev 2015; Simut 2011, p. 104; 2016; Švaňa 2015; 2016). Among the most significant contributions to the critical reflection on the above concept are Münz's analysis of ethics of social consequences as well as his problematising of the notion 'social' mainly within human society and avoiding the stimuli of natural science for the elaboration of ethics and morality (Münz 2002, pp. 279-283). Petr Jemelka and Katarína Komenská expressed similar ideas, emphasising the need to consider the findings of natural sciences, especially ecology (Jemelka 2017; Komenská 2016). Moreover, Kiššss objection could also be mentioned to excessive attention paid to metaethical issues while partially overlooking applied ethics (Kišš 2011, p. 21); as well as Josef Kuře's idea characterising this concept as an example of moderate ethical realism which suggests paying more attention to the acting agent. Daniela Navrátilová also points to the need of complex perception of actions and the moral agent with regard to his characteristic features (Kuře 2011, p. 34; Navrátilová 2011, pp. 43-44).

${ }_{2}$ The original concept of the theory of moral/right action has been further developed especially by Ján Kalajtzidis and completed by an analysis of just action, which is not, however, within the scope of this paper, as it falls beyond a comparison with Moore's concept of right action (Kalajtzidis 2012, pp. 160-189).
} 
judgements are moral and immoral behaviour, and action is evaluated as right or wrong on a lower level (Gluchman, 2001, pp. 633-634).

According to Moore, the main criterion of right action is consequences resulting from the action itself. He refuses a restricted approach to the perception of correctness as a criterion and emphasises the importance of only considering correct such action which brings about the best possible consequences (Moore, 2005, p. 70). At the theoretical level at least, such a state of affairs is possible where more than one action is equally right. Then, any of these alternatives could be considered equally right. Unlike Moore's concept, I formulated theory of moral/right action depending on the amount of positive and negative consequences, or a prevalence of the former over the latter or vice versa. The evaluation scale of judgements takes the form of evaluating action as moral (if there is a maximum or greatly significant prevalence of positive over negative consequences) or right (if the prevalence of positive over negative consequences is less significant). Conversely, action is considered immoral (if there is a maximum or greatly significant prevalence of positive over negative consequences) or wrong (if there is a more minor prevalence of negative over positive consequences) (Gluchman, 2001, pp. 633-634). Daniela Navrátilová, not quite fairly, criticises ethics of social consequences claiming that, in spite of its dismissive view of the utilitarian criterion of right action in the form of maximisation, it actually latently accepts this criterion by using it to assess moral action (Navrátilová, 2011, p. 40). She, however, ignores the fact that a maximum prevalence of positive over negative social consequences is not unconditional in evaluating the rightness of action, but rather crediting such an alternative which might or might not be achieved for the action of a moral agent to be considered acceptable by a moral community, or from the viewpoint of ethics of social consequences.

Moore in his theory of right action also paid attention to the study of the extent to which intentions can play a role as a criterion of right action. He claimed that a general opinion could be accepted according to which good intentions tend to give rise to right action while bad intentions lead to wrong action. The role of intentions can, therefore, be accepted in such moral judgments. He, however, pointed out that this tendency is not absolute (Moore, 2005, pp. 94-95). In Moore's view, there is a kind of moral judgment in which it is possible to take intentions of action into consideration, and these are judgments of such action which could be praised and such that should be condemned. At first sight it could seem that right action is praised while wrong action is condemned. Moore, however, proves that there is no direct relationship between these two (Moore, 2005, pp. 97-98), as not all that is right deserves to be praised and, on the other hand, not all that is wrong must be necessarily condemned. ${ }^{3}$

Similarly to Moore, bearing in mind the intentions of an acting moral agent, I also consider such action immoral which directly, based on bad intentions on the part of the moral agent, caused moral harm. I, however, unlike Moore, think of such action as wrong, which, in spite of the good intentions of a moral agent, caused a prevalence of negative over positive consequences as a result of unforeseen circumstances. In my view, based on the above, such a situation is possible when the action did not bring about any, or hardly any, positive but merely negative consequences; however, if the intention(s) was (were) good, such action can be assessed not as immoral but rather wrong. Conversely, a situation can arise when the prevalence of negative over positive consequences is less significant, but the action is assessed as immoral. Such an assessment is given by the fact that, as a result of external circumstances, the worst alternative, originally set in the intentions of the agent's action, which would merely bring about negative and no, or hardly any, positive consequences, was not realised. The criterion to differentiate between these two kinds of action as wrong and immoral is the presence of an bad intention rather than the amount of negative consequences

\footnotetext{
${ }^{3}$ In this context, Michael J. Zimmerman claims that, although according to Moore it is wrong for Jill to give drugs to John, it does not mean such action should be considered blameworthy (Zimmerman 2006, p. 338).
} 
caused. The consequences, or, more specifically, the prevalence of negative over positive consequences, are the primary criterion according to which these kinds of actions can be determined. From this, an application of a finer criterion follows, according to which intentions for the action of a moral agent are considered (Gluchman, 2001, p. 634).

In my view, more complex situations can be solved by expressing two evaluative judgements. In right action based on wrong intentions it could be stated that such action is, from the consequentialist viewpoint, right; however, from the intention-related viewpoint, it is not praiseworthy; which, however, does not mean it is blameworthy. At first sight, this is a rather complicated assessment which could be shortened into stating that such action is right but not praiseworthy. On the other hand, wrong action based on good intentions could, from the consequentialist viewpoint, be considered wrong; however, from the intention-related viewpoint, it is not blameworthy; which, however, still does not mean it is praiseworthy. Briefly expressed, such action is wrong but not blameworthy. The situation is less complex in the case of other kinds of action, as moral or right action with good intentions which brings about a prevalence of positive over negative consequences can be clearly considered moral, or right, which is, at the same time, praiseworthy. On the other hand, immoral, or wrong, action based on bad intentions can be considered immoral, or wrong, and, at the same time, blameworthy (Gluchman, 2001, p. 640).

Daniela Navrátilová praises the application of intentions as a criterion of assessing action in ethics of social consequences, as it, in her view, aids in specifying the evaluative judgements regarding the action of a moral agent. Should the intentions of action not be regarded, then, in her view, the same assessments of action based on good or bad intentions, merely considering the consequences of such action, which might also be influenced by external factors, would sound absurd (Navrátilová, 2011, p. 40). Similarly, Ján Kalajtzidis positively assesses the fact that the acceptance of intentions plays a role "[...] when determining the extent of punishment or reward in the context of responsibility" (Kalajtzidis, 2011, p. 107).

Unlike my opinion, Moore could see a possible solution to the problem in this objection by getting over "[...] by reference to the distinction between what is right or wrong, on the one hand, and what is morally praiseworthy or blameworthy on the other. What we should naturally say of a man whose action turns out badly owing to some unforeseen accident when he had every reason to expect that it would turn out well, is not that his action was right, but rather that he is not to blame. And it may be fully admitted that in such a case he really ought not to be blamed; since blame cannot possibly serve any good purpose, and would be likely to do harm. But, even if we admit that he was not to blame, is that any reason for asserting also that he acted rightly? I cannot see that it is; and therefore I am inclined to think that in all such cases the man really did act wrongly, although he is not to blame, and although, perhaps, he even deserves praise for acting as he did" (Moore, 2005, p. 100). Ingmar Persson adds that, according to Moore, the effort to maximise actual consequences does not mean praise for the acting moral agent, just as the opposite approach does not mean condemnation of an individual for his action (Persson, 2008, p. 351).

Another part of the theory of moral/right action in ethics of social consequences is obligatory action where likely consequences, which might cause a (maximum to minimum) prevalence of positive over negative consequences, are the criteria. I claim that probable positive consequences are closely connected to good intentions the aim of which is to achieve a prevalence of positive over negative consequences. What, however, plays an important role is the agent's moral cognition, reasoning and decision making in the process of recognising probable consequences, their analysis and deciding to pursue such action which is likely to bring about a prevalence of positive over negative consequences (Gluchman, 2001, p. 642). 
Achieving the best possible results is not a criterion of an obligatory action, but rather achieving any prevalence of probable positive over negative consequences.

In the context of obligatory actions, I do not consider necessary to state that its criterion is probable positive consequences based on good intentions; it suffices to state that the criterion of an obligatory action is probable positive consequences. It is obvious that bad intentions are aimed at achieving negative rather than positive probable consequences. In the same way, in my view, probable positive consequences are those that are likely to cause a (maximum to minimum) prevalence of positive over negative consequences and probable negative consequences are those that are probably to cause a (maximum to minimum) prevalence of negative over positive consequences (Gluchman, 2001, p. 642).

Similarly to obligatory action, I also defined the criterion for such action that should be avoided. These are actions based on bad intentions with the aim of causing a prevalence of negative over positive probable consequences. In the context of assessing action as immoral and wrong, I believe it is obvious that such action that should be avoided is an immoral action, i.e. action based on bad intentions which causes a maximum or greatly significant prevalence of negative over positive (actual or probable) consequences. I further claim that in relation to wrong action, one has to be more careful, as, while in the case of immoral action, it is clear this includes actions based on bad intentions causing a maximum or a highly significant prevalence of negative over positive consequences, wrong action refers to such actions which cause a (maximum to minimum) prevalence of negative over positive consequences and might be either based on ill or even good intentions. In the case of bad intentions that have lead to an actual action which caused some (not maximum) prevalence of negative over positive (actual or probable) consequences, it is clear that such wrong action should be avoided. It is not, however, quite clear in the case of action based on good intentions.

Much like Moore, ethics of social consequences deals with the issue of action assessment based on consequences. However, the question is what consequences should be taken into consideration when reaching an evaluative judgement; probable or actual? I claim that, based on probable consequences, it is almost identical with assessment based on intentions, which, however, does not treat the merits of the case, as it is obvious that probable positive consequences are based on good intentions while probable negative consequences are based on bad intentions. In probable consequences, even when considering external circumstances and influences, one expects them to work in a particular (positive or negative) way, which is also considered in one's reasoning and decision making. It can, therefore, be claimed that, to a certain extent, there is a direct proportional relationship between good intentions and probable positive consequences on the one hand, and bad intentions and probable negative consequences on the other. It is difficult to imagine such a situation when someone, based on good intentions, wished to directly cause a prevalence of negative over positive consequences and, contrariwise, based on bad intentions wished to achieve a prevalence of positive over negative consequences. Assessment based on probable consequences is only justified as informative or preliminary in a particular phase, most often before it has started. Later, when it has started, the degree of its justification gradually falls and when finished, assessment based on probable consequences loses any justness, as it might be rather inaccurate, misinterpretive, or even misleading compared to reality.

Moore came to the same conclusion earlier when he pointed out that actual consequences might not correspond with the agent's intentions and reasoning, as even with the best effort, any unforeseeable event can change them considerably. On the other hand, should one follow Moore and accept probable consequences as a criterion, only that would be assessed which the agent is able to pursue in the moment of decision making. What he considers difficult is that probable consequences are based on a belief which might not, in the end, prove to be true 
(Moore, 2005, p. 99). He, nevertheless, claims that a moral agent should opt for such action he believes to be the best possible. However, "[...] the question whether an action is right or wrong always depends on its actual consequences. There seems no sufficient reason for holding either that it depends on the intrinsic nature of the action, or that it depends upon the intention, or even that it depends on the probable consequences" (Moore, 2005, p. 101).

In theory of moral/right action, I approach reasoning over the importance and role of probable consequences in a broader context. Basing the assessment of action on probable consequences is quite closely connected with the assessment of intentions; in the context of assessing actions as praiseworthy or blameworthy, the role of probable consequences is substantially different from that in assessing action as moral/right or immoral/wrong. When assessing action as praiseworthy or blameworthy, one also considers intentions, i.e. probable consequences which could be brought about onto the moral agent in the process of moral cognition, reasoning and making decisions about particular action. I believe that in this kind of assessment, moral and right action based on intentions, which is also praiseworthy, is different from right action which lacks a good intention and is neither praiseworthy nor blameworthy. On the other hand, if one claimed that immoral and wrong action based on a bad intention is blameworthy, wrong action based on right intentions is thought to be neither blameworthy nor praiseworthy. In this approach, assessments based on actual and probable consequences overlap.

I further claim that where actual and probable consequences are in agreement, one can talk of praiseworthy or blameworthy action, depending on the kind of agreement. Action accompanied by a congruence of good intentions, probable and actual positive consequences, is considered praiseworthy. However, if a congruence of bad intentions, probable and actual negative consequences is concerned, such action is considered blameworthy. If there is no congruence between probable and actual consequences, i.e. where actual consequences are in (maximum to minimum) conflict with probable consequences, such action is assessed as neither praiseworthy nor blameworthy. In the case of such a conflict, the action can either be right or wrong, while, in the former case, the outcome of bad intentions and probable negative consequences is actual positive consequences. In the latter case, the outcome of good intentions and probable positive consequences is actual negative consequences. Actual consequences play a decisive role in the assessment of action as moral or immoral, right or wrong; while when assessing action as praiseworthy or blameworthy, the decision depends on the degree to which actual and probable consequences are in agreement. What is decisive in defining obligatory actions are probable consequences, as obligatory actions are typical of not knowing what the actual consequences will be (Gluchman, 2001, p. 647).

Josef Kurre, however, points out that it could be problematic (not only in ethics of social consequences but in consequentialist ethical concepts in general) to assess all consequences, especially in such decisions and actions which concern large social groups, nations or countries. In his view, in the above cases it might be difficult to differentiate between positive and negative consequences, especially if the decisions and actions in question concern several social groups, nations, countries or cultures (Kuře, 2011, pp. 30-31). In the context of theory of moral/right action, Grzegorz Grzybek also poses the question how to predict the quality of one's action with regard to future consequences. He agrees, to an extent, with me that this primarily depends on the intellectual and cognitive abilities of a moral agent to, in terms of his own capacity and ability, predict probable consequences of his actions (Grzybek, 2011, p. 188).

Moore, in his theory of right action, dealt with the study of the relationship between the obligation to pursue certain action and its usefulness resulting from producing the best possible consequences. In his opinion, it is often claimed that "[...] whatever is expedient is always also a duty, and that whatever is a duty is always also expedient. That is to say, it does 
maintain that duty and expediency coincide; but it does not maintain that the meaning of the two words is the same" (Moore, 2005, p. 89). Moore counters objections which the claim that what is useful might not always be obligatory by pointing out that this is valid providing each and every best possible consequence is taken into consideration. Based on this he then presumes it is hard to imagine that to perform an obligation could be, in this sense, useless or that useful action could even be considered wrong.

Following Moore's concept, I also explore what the criterion is of assessing usefulness or uselessness (or, possible, harmfulness) of action. In my opinion, the overall amount of positive or negative consequences does not refer to the actual degree of usefulness or uselessness of action. It might be a certain attribute or an auxiliary criterion when considering the degree of usefulness of the given action; however, the actual level to express the degree of an action's usefulness is a prevalence of positive over negative consequences and the degree of uselessness of action is a prevalence of negative over positive consequences. One also has to consider the presence of the other consequences in action (besides those that prevail), in which case, according to him, it could be claimed that the extent to which positive consequences prevail over negative ones determines the level of usefulness of right action. Analogously, this also applies with regard to wrong action, i.e. the extent of prevalence of negative over positive consequences determines the level of uselessness of the action. The lesser the extent of positive consequences, the greater the need to point out that, in such action, its usefulness prevails over its uselessness (or harmfulness). Similarly, in wrong action, the lesser the extent of negative over positive consequences, the greater the need to point out that the level of harmfulness (or uselessness) of such action is not great. If a great prevalence is present, it suffices to assess such action as highly useful, or highly harmful (Gluchman, 2001, p. 653).

\section{Conclusion}

Moore considered determining the criterion for right and wrong action an essential aspect of ethics. In this context, he claimed that "almost everybody is agreed that certain kinds of actions ought, as a general rule, to be avoided; and that under certain circumstances, which constantly recur, it is, as a general rule, better to act in certain specified ways rather than in others. There is, moreover, a pretty general agreement, with regard to certain things which happen in the world, that it would be better if they never happened, or, at least, did not happen so often as they do: and with regard to others, that it would be better if they happened more often than they do" (Moore, 2005, p. 1).

I think that above mentioned Moore's quotation is a very good contribution to using his theory of right action like challenge for its application in analysing the ethical problems. We also see that Moore's theory has been very useful and productive starting point for establishing theory of moral/right action in ethics of social consequences. Due to his contribution it was possible to develop theory of moral/right action and use it more appropriate for analyses and evaluation of difficult ethical and moral issues in the contemporary humans' individual and social lives. It is due to a fact that theory of moral/right action is focused on real moral problems of contemporary people. Ability of ethics of social consequences to analyse and respond to current ethical and moral challenges is also result of Moore's contributions to its development. Really, I fully agree with Moore's idea that in human history there were (and are) many tragic events and it could be much better if they never happened. I think that it is one of Moore's greatest messages to humankind and it is necessary to keep it in mind. 


\section{Acknowledgement}

This paper is a part of the research project - VEGA 1/0629/15 Ethics of social consequences in context of contemporary ethical theories.

Vasil Gluchman is Professor of Philosophy and Ethics at the Institute of Ethics and Bioethics, University of Prešov (Slovakia). He is an author of Profesijná etika ako etika práce a etika vzt'ahov [Professional Ethics as Work Ethic and Ethics of Relationships], Prešov: FF PU 2014; Etika a reflexia morálky [Ethics and Reflection of Morality], Prešov: FF PU 2008; Human Being and Morality in Ethics of Social Consequences, Lewiston, NY: Edwin Mellen 2003; Slovak Lutheran Social Ethics, Lewiston, NY: Edwin Mellen 1997; editor of Ethical Thinking on Past \& Present (ETPP 2013), Prešov: VPU 2014; Morality: Reasoning on Different Approaches, Amsterdam \& New York: Rodopi 2013, and Morality of the Past from the Present Perspective: Picture of Morality in Slovakia in the First Half of the Twentieth Century, Newcastle: Cambridge Scholars Publishing 2007.

\section{Corresponding author:}

Vasil Gluchman, Institute of Ethics and Bioethics, University of Prešov, 17. novembra 1, SK-08078 Prešov (Slovakia)

email: gluchman@unipo.sk

\section{References}

DOMAGAŁA, J. (2015): Vasil Gluchman's ethics of social consequences and the professional ethics of a Polish Police Officer. In: Ethics \& Bioethics (in Central Europe), 5(12), pp. 115-119.

DUBIEL-ZIELIŃSKA, P. (2013): "Ethics of social consequences" and "Ethics of Development" as Theories belonging to Stream of Ethics of Act. In: Ethics \& Bioethics (in Central Europe), 3(3-4), pp. 173-188.

DUBIEL-ZIELIŃSKA, P. (2015): Consequentialist and non-consequentialist overtones of the Code of ethics of an academic staff member in light of ethics of social consequences. In: Ethics \& Bioethics (in Central Europe), 5(1-2), pp. 105-113.

DUBIEL-ZIELIŃSKA, P. (2016): Moral dilemmas in professions of public trust and the assumptions of ethics of social consequences. In: Ethics \& Bioethics (in Central Europe), 6(1-2), pp. 19-32.

GLUCHMAN, V. (2000): Utilitarizmus G. E. Moora [G. E. Moore's utilitarianism]. In: G. E. Moore: Etika [Ethics], trans. and ed. by V. Gluchman \& M. Gluchmanová. Prešov: LIM, pp. 9-23.

GLUCHMAN, V. (2001): Teória správneho v etike sociálnych dôsledkov [Theory of right in ethics of social consequences]. In: Filosofický časopis, 49(4), pp. 633-654.

GLUCHMAN, V. (2003): Human being and morality in ethics of social consequences. Lewiston, NY: Edwin Mellen Press.

GLUCHMAN, V. (2007): Human dignity and non-utilitarian consequentialist "Ethics of social consequences". In: H. Tepe \& S. Voss (eds.): The proceedings of the twenty-first world congress of philosophy, vol. 1 Ethics. Ankara: Philosophical Society of Turkey, pp. 159-165.

GLUCHMAN, V. (2009): Dignity and human dignity as methodological basis of bioethics. In: V. Gluchman (ed.): Bioethics in Central Europe: Methodology and Education. Prešov: FF PU, pp. 73-86.

GLUCHMAN, V. (2012): Ethics of social consequences - methodology of bioethics education. In: Ethics \& Bioethics (in Central Europe), 2(1-2), pp. 16-27. 
GLUCHMAN, V. (2016): Disaster issues in non-utilitarian consequentialism. In: Human Affairs, 26(1), pp. 52-62.

GLUCHMAN, V. (2017): Nature of dignity and human dignity. In: Human Affairs, 27(2), pp. 131-144.

GLUCHMANOVÁ, M. (2013): The Teacher as a Moral Agent: Humanity and Human Dignity in the Teaching Profession. In: V. Gluchman (ed.): Morality: Reasoning on Different Approaches. Amsterdam \& New York: Rodopi, pp. 141-160.

GRZYBEK, G. (2011): Etika sociálnych dôsledkov a etika vývoja [Ethics of social consequences and development ethics]. In: V. Gluchman et al.: Hodnoty v etike sociálnych dôsledkov [Values in ethics of social consequences]. Prešov: Grafotlač, pp. 186-190.

JACKSON, F. (1991): Decision-Theoretic Consequentialism and the Nearest and Dearest Objection. In: Ethics, 101(3), pp. 461-482.

JEMELKA, P. (2017): Ethics of social consequences and its bioethical aspects as reflected in potential criticism. In: V. Gluchman (ed.): 16th International Conference on "Ethical Thinking - Past \& Present" (ETPP 2016/16). Prešov: FF PU, pp. 109-119.

KALAJTZIDIS, J. (2011): Problematika mravných subjektov v etike sociálnych dôsledkov [Moral agents' issues in ethics of social consequences]. In: V. Gluchman et al.: Hodnoty $v$ etike sociálnych dôsledkov [Values in ethics of social consequences]. Prešov: Grafotlač, pp. 86-121.

KALAJTZIDIS, J. (2012): Etika sociálnych dôsledkov a hospodárska etika (so zameraním na finančný sektor) [Ethics of social consequences and business ethics]. Brno: Tribun EU.

KALAJTZIDIS, J. (2013): Ethics of social consequences as a contemporary consequentialist theory. In: Ethics \& Bioethics (in Central Europe), 3(3-4), pp. 159-171.

KIŠS̆, I. (2011): Zápas o morálne hodnoty vo filozofickej etike Vasila Gluchmana [Struggle for moral values in Vasil Gluchman's philosophical ethics]. In: V. Gluchman et al.: Hodnoty $v$ etike sociálnych dôsledkov [Values in ethics of social consequences]. Prešov: Grafotlač, pp. 9-23.

KOMENSKÁ, K. (2016): Bioetické reflexie pohrôm a katastrof - nové výzvy pre súčasnú etiku [Bioethical reflection of disasters and catastrophes - new challenges for contemporary ethics]. In: Filosofický časopis, 64(5), pp. 773-782.

KUŘE, J. (2011): Subjektivní a objektivní moment v etice sociálních důsledků [Subjective and objective aspect in ethics of social consequences]. In: V. Gluchman et al.: Hodnoty v etike sociálnych dôsledkov [Values in ethics of social consequences]. Prešov: Grafotlač, pp. 24-36.

MISSERI, L. (2014): Gluchman y su ética socio-consecuencialista. In: V. Gluchman: Dignidad y consecuencias: ensayos de una ética socio-consecuencialista, 1a ed. Mar del Plata: Kazak Ediciones, pp. 5-17.

MOORE G. E. (2000): Principia Ethica, ed. by T. Baldwin. Cambridge: Cambridge University Press.

MOORE, G. E. (2005): Ethics, ed. by W. H. Shaw. Oxford: Oxford University Press.

MÜNZ, T. (2002): Etika sociálnych dôsledkov Vasila Gluchmana [Vasil Gluchman's ethics of social consequences]. In: Filozofia, 52(2), pp. 276-283.

NAVRÁTILOVÁ, D. (2011): Limity etiky sociálnych dôsledkov v kontexte súčasného etického myslenia [Limits of ethics of social consequences in context of contemporary ethical thinking]. In: V. Gluchman et al.: Hodnoty v etike sociálnych dôsledkov [Values in ethics of social consequences]. Prešov: Grafotlač, pp. 37-45.

PETTIT, P. (1988): The Consequentialist Can Recognise Rights. In: The Philosophical Quarterly, 38(150), pp. 42-55.

PETTIT, P. (1989): Consequentialism and Respect for Persons. In: Ethics, 100(1), pp. 116126. 
PETTIT, P. (1991): Consequentialism. In: P. Singer (ed.): A Companion to Ethics. Oxford: Basil Blackwell, pp. 230-240.

PETTIT, P. (1994): Consequentialism and Moral Psychology. In: International Journal of Philosophical Studies, 2(1), pp. 1-17.

PETTIT, P. (1997): The Consequentialist Perspective. In: M. Baron, P. Pettit \& M. Slote: Three Methods of Ethics. Oxford: Blackwell, pp. 92-174.

PERSSON, I. (2008): A Consequentialist Distinction between What We Ought to Do and Ought to Try. In: Utilitas, 20(3), pp. 348-355.

SACHDEV, K. N. (2015): Normative analysis of human dignity among professionals. In: Ethics \& Bioethics (in Central Europe), 5(3-4), pp. 205-210.

SEN, A. (1982): Rights and Agency. In: Philosophy \& Public Affairs, 11(1), pp. 3-39.

SEN, A. (1983): Evaluator Relativity and Consequential Evaluation. In: Philosophy \& Public Affairs, 12(2), pp. 113-132.

SEN, A. (1993): Utilitarianism and Welfarism. In: P. Pettit (ed.): $\square$ Consequentialism. Aldershot \& Brookfield: Dartmount, pp. 15-41.

SIMUT, C. C. (2011): Essentials of Catholic Radicalism: An Introduction to the Lay Theology of Vito Mancuso. Frankfurt am Main: Peter Lang.

SIMUT, C. C. (2016): Staying young today: Vito Mancuso's Hegelian theology through the lens of Vasil Gluchman's ethics of social consequences. In: Ethics \& Bioethics (in Central Europe), 6(1-2), pp. 5-17.

SLOTE, M. (1985): Common-Sense Morality and Consequentialism. London \& Boston: Routledge \& Kegan Paul.

SLOTE, M. (1989): Beyond Optimizing: A Study of Rational Choice. Cambridge, MA \& London: Harvard University Press.

SLOTE, M. (1993): Satisficing Consequentialism. In: P. Pettit (ed.): $\square$ Consequentialism. Aldershot \& Brookfield: Dartmount, pp. 351-375.

ŠVAŇA, L. (2015): War, terrorism, justice and ethics of social consequences. In: Ethics \& Bioethics (in Central Europe), 5(3-4), pp. 211-225.

ŠVAŇA, L. (2016): On two modern hybrid forms of consequentialism. In: Ethics \& Bioethics (in Central Europe), 6, (3-4), pp. 157-166.

ZIMMERMAN, M. J. (2006): Is Moral Obligation Objective or Subjective? In: Utilitas, 18(4), pp. 329-361. 